\title{
Investigation of the Wettability Using Contact Angle Measurements of Green Polyethylene Flat Films and Expanded Vermiculite Clay Treated by Plasma
}

\author{
Isaías Damasceno da Conceição ${ }^{a}$, Lucas Rafael Carneiro da Silva ${ }^{(\circledR)}$, Tatianny Soares Alves ${ }^{a, b}$, \\ Heurison de Sousa e Silva ${ }^{a, c}{ }^{\mathbb{D}}$, Renata Barbosa ${ }^{a, b} * \mathbb{(}$, Rômulo Ribeiro Magalhães de Sousa $a^{a, d}$ \\ a Programa em Ciência e Engenharia dos Materiais, Centro de Tecnologia, Universidade Federal do Piauí, \\ Teresina, PI, Brasil. \\ ${ }^{b}$ Curso de Engenharia de Materiais, Centro de Tecnologia, Universidade Federal do Piaui, Teresina, PI, Brasil. \\ ${ }^{c}$ Departamento de Física, Centro de Ciências da Natureza, Universidade Federal do Piauí, Teresina, PI, Brasil. \\ ${ }^{d}$ Curso Engenharia Mecânica, Centro de Tecnologia, Universidade Federal do Piauí, Teresina, PI, Brasil.
}

Received: December 21, 2018; Revised: June 23, 2019; Accepted: June 25, 2019

\begin{abstract}
Polyethylene (PE) is a polymer that has a low adhesion property, which is related to its low surface energy. However, the plasma treatment aims the modification of the surface properties without affecting the polymer structure. In this sense, the objective of this work was to prepare biocomposite films via flat extrusion with Green PE matrix and Expanded Vermiculite Clay (VMT), contents of 1,3 and $6 \%$. The films were treated by plasma in two different ways: Oxygen $\left(\mathrm{O}_{2}\right)$ atmosphere (Condition 1); and Argon/Hydrogen $\left(\mathrm{Ar} / \mathrm{H}_{2}\right)$ atmosphere followed by a plasma treatment under $\mathrm{O}_{2}$ atmosphere (Condition 2). The results of the contact angle measurements indicated that the incorporation of VMT and the conditions used for plasma treatment increased the films wettability due to the hydrophilic character of VMT and also as a consequence of the plasma. In contrast, the XRD diffractograms indicated that there were no significant changes in the films structure.
\end{abstract}

Keywords: Contact Angle, biocomposite, plasma, green polyethylene, vermiculite.

\section{Introduction}

Polyolefin polymers, such as polyethylene (PE) and polypropylene (PP), are of great commercial interest and represent an important division of the plastics family, with more than half of commercial polymers manufactured worldwide ${ }^{1,2}$. Due to the lack of a functional group, the polyolefins have a low adhesion property ${ }^{3}$. Polymer films of PE and PP show weak wettability and low printing efficiency as an effect of their hydrophobic character, and many surface treatment techniques are being used to overcome these problems by doing the surface modification of the films. As a result of the treatment, the surface free energy and the hydrophilic character are elevated by the addition of polar functional groups containing the oxygen on the film surface ${ }^{4}$.

Plasma treatment has been widely used and has shown great efficiency in modifying surface properties of several types of materials ${ }^{5}$. During the process, this technique does not use water and chemicals, being considered a technology that does not harm the environment. It is a versatile technique that only reaches the initial atomic layers on the surface, not affecting the properties that depend on the volume ${ }^{6}$.

The existence of polar and non-polar groups on the surface directly influences the wettability property, so it can be pointed out that if the liquid wets the surface of the material at angles between $0^{\circ}<\theta<90^{\circ}$ it is said to be hydrophilic, and hydrophobic if the angle is between $90^{\circ}<\theta<180^{\circ 7}$. When a drop of water comes in contact with a hydrophilic surface it tends to spread,

*E-mail:rrenatabarbosa@yahoo.com causing a low $\theta$ or equal to zero. Conversely, the drop will be repelled, as there will be minimal contact with the surface, resulting in a high $\theta^{8}$. The technique used to determine the $\theta$ is relatively low cost and, for this reason, is easily available, where the most used method is the sessile drop ${ }^{9,10}$.

The PE has a limited use due to its low surface free energy, leading to weak wettability and poor adhesion. For PE to have a good adhesion property, its surface free energy must be higher than the material in contact. Thus, for more efficient wetting by a liquid, the surface free energy must exceed the surface tension of the liquid ${ }^{11}$.

According to TUNNEY and DETELLIER (1996) ${ }^{12}$, the polymers can interact with the clay minerals outer surface, which makes the addition of Expanded Vermiculite (VMT) in the Green PE matrix a good alternative, in which the extrusion processing of the Green PE/VMT would be favorable because it is a stage of industrial processing that exhibits advantages such as the low cost of production and to allow the use in a wide variety of polymers ${ }^{13}$.

The objective of this work is to prepare a film extrusion with Green PE matrix in three VMT proportions, 1, 3 and 6\%, after the treatment of its surface by plasma in two different ways: under oxygen $\left(\mathrm{O}_{2}\right)$ atmosphere (Condition $\left.1-\mathrm{C}_{1}\right)$; and Argon/Hydrogen $\left(\mathrm{Ar} / \mathrm{H}_{2}\right)$ atmosphere followed by a subsequent plasma treatment under $\mathrm{O}_{2}$ atmosphere (Condition $2-\mathrm{C}_{2}$ ). The wettability of the films surface was measured before and after treatment using the contact angle, as well as characterized by $\mathrm{X}$-ray diffraction (DRX). 


\section{Materials and Methods}

\subsection{Materials}

As the polymer matrix was used the Green PE grade SGM9450F, flow rate $\left(190^{\circ} \mathrm{C} / 5 \mathrm{~kg}\right)$ of $0.33 \mathrm{~g} .10 \mathrm{~min}^{-1}$, density of $0.952{\mathrm{~g} . \mathrm{cm}^{-3}}^{3}$, in which it was acquired at Braskem-SA, and as a mineral charge was used the VMT clay supplied by Mineração Pedra Lavrada Ltda. (PB).

\subsection{Obtaining the system}

In order to prepare the systems, a Single Screw Extruder was used $(\mathrm{L} / \mathrm{D}=26)$, model $\mathrm{AX}-16$ by AX Plastics, operating with temperatures varying from the first to the third zone, respectively, between 200,205 and $210{ }^{\circ} \mathrm{C}$ and screw speed of $50 \mathrm{rpm}$. Initially, the Green PE matrix was extruded without presence of VMT (PPure) and then the systems were processed incorporating 1,3 and $6 \%$ of VMT in the polymer matrix, forming the $\mathrm{P} 1 \mathrm{~V}, \mathrm{P} 3 \mathrm{~V}$, and $\mathrm{P} 6 \mathrm{~V}, \mathrm{P}$ corresponding to the Green PE; 1,3 and 6 means the $\%$ of clay and V refers to VMT.

\subsection{Flat film extrusion}

The obtained systems were oven-dried at $60{ }^{\circ} \mathrm{C}$ for 24 hours and used in the production of the flat films, by means of an extruder with a flat die and cylindrical cooling rollers. The temperature condition varied from the first to the third zone, respectively, between 205,210 and $180^{\circ} \mathrm{C}$ and screw speed at $60 \mathrm{rpm}$. The films thickness data were obtained by a thickness gauge, $0.12 \mathrm{~mm}$ (PPure), $0.23 \mathrm{~mm}$ (P1V), 0.25 $\mathrm{mm}(\mathrm{P} 3 \mathrm{~V})$ and $0.35 \mathrm{~mm}(\mathrm{P} 6 \mathrm{~V})$, with an average of 7 films.

\subsection{Plasma treatment of the film surface}

The size of the Plasma-treated films was $14 \times 16 \mathrm{~cm}^{2}$, in which their surfaces were treated in a continuous reactor by SDS Plasma in two different conditions. In the first condition, the films were treated only under $\mathrm{O}_{2}$ atmosphere, as shown in Table 1.

Table 1. Plasma treatment condition $1\left(\mathrm{C}_{1}\right)$ of the films.

\begin{tabular}{lc}
\hline \multicolumn{2}{c}{ Treatment under $\mathbf{O}_{2}$ atmosphere } \\
\hline Gas & $\mathbf{O}_{2}$ \\
\hline Flow $\left(\mathrm{cm}^{3} \cdot \mathrm{min}^{-1}\right)$ & 10 \\
\hline Pressure $(\mathrm{mBar})$ & 0.4 \\
\hline Temperature $\left({ }^{\circ} \mathrm{C}\right)$ & 60 \\
\hline Time $(\min )$ & 10 and 20 \\
\hline
\end{tabular}

In the second condition, the pre-treatment under the mixture of Ar and $\mathrm{H}_{2}$ was used and then the treatment under $\mathrm{O}_{2}$ atmosphere was performed, as shown in Table 2 .

\subsection{Films characterization}

\subsubsection{Contact Angle}

For the contact angle analysis, the films samples were used in the dimensions of $3 \times 1 \mathrm{~cm}^{2}$. The wettability of the films surface was based on the sessile drop method, from which a $16 \mu \mathrm{L}$ drop of ultra-pure water was softly deposited on the surface, and the angle formed between the drop and the surface was determined by image analysis via Software CAM 2008/KSV Instruments. The contact angle was reported through the mean of 20 measurements in each film.

\subsubsection{X-Ray Diffraction (XRD)}

The analyzes were performed on a SHIMADZU XRD$6000 \mathrm{X}$-ray diffractometer, operating in the angular range (2 $\theta$ ) between 4 and $28^{\circ}$, using K- $\alpha$ of cooper as incident radiation, a voltage of $40 \mathrm{kV}$ and current of $30 \mathrm{~mA}$. The analyzes were carried out at the Interdisciplinary Laboratory of Advanced Materials (LIMAV) at UFPI.

\section{Results and Discussion}

\subsection{Contact Angle}

The wettability is a phenomenon resulting from the molecular interactions between two fluids ${ }^{14}$. Thus, the existence of polar and non-polar groups on the surface directly influences the wettability property ${ }^{7}$. The Figure 1 shows the wettability behavior for PPure films as well as for P1V, P3V, and P6V films that were treated through $\mathrm{C}_{1}$.

Initially, it was observed that the PPure film surface (untreated) exhibited characteristics of a hydrophobic surface with a contact angle of $104.12^{\circ}$. For the untreated biocomposites, it was observed that the incorporation of VMT clay into the pure polymer matrix decreased the contact angle, since $\mathrm{P} 1 \mathrm{~V}, \mathrm{P} 3 \mathrm{~V}$, and $\mathrm{P} 6 \mathrm{~V}$ presented the contact angle values equal to $88.39^{\circ}, 70.79^{\circ}$, and $83.04^{\circ}$, respectively, in which the P3V film reached the lowest value for contact angle. Therefore, it's evident that the addition of VMT to the pure matrix resulted in a decrease in the contact angle, even without the use of $\mathrm{O}_{2}$ plasma treatment. This contact angle reduction occurred due to the hydrophilic character of VMT.

Table 2. Plasma treatment condition $2\left(\mathrm{C}_{2}\right)$ of the films.

\begin{tabular}{lclc}
\hline & Pre-treatment & \multicolumn{2}{c}{ Treatment under $\mathbf{O}_{2}$ atmosphere } \\
\hline Gases & $\mathbf{5 0} \mathbf{0} \mathbf{A r} / \mathbf{5 0} \% \mathbf{H}_{2}$ & \multicolumn{1}{c}{ Gas } & $\mathbf{O}_{2}$ \\
\hline Flow $\left(\mathrm{cm}^{3} \cdot \mathrm{min}^{-1}\right)$ & 10 & Flow $\left(\mathrm{cm}^{3} \cdot \mathrm{min}^{-1}\right)$ & 0.4 \\
\hline Pressure $(\mathrm{mBar})$ & 1.3 & Pressure $(\mathrm{mBar})$ & 60 \\
\hline Temperature $\left({ }^{\circ} \mathrm{C}\right)$ & 60 & Temperature $\left({ }^{\circ} \mathrm{C}\right)$ & 10 and 20 \\
\hline Time $(\mathrm{min})$ & 20 & Time $(\mathrm{min})$ & \\
\hline
\end{tabular}




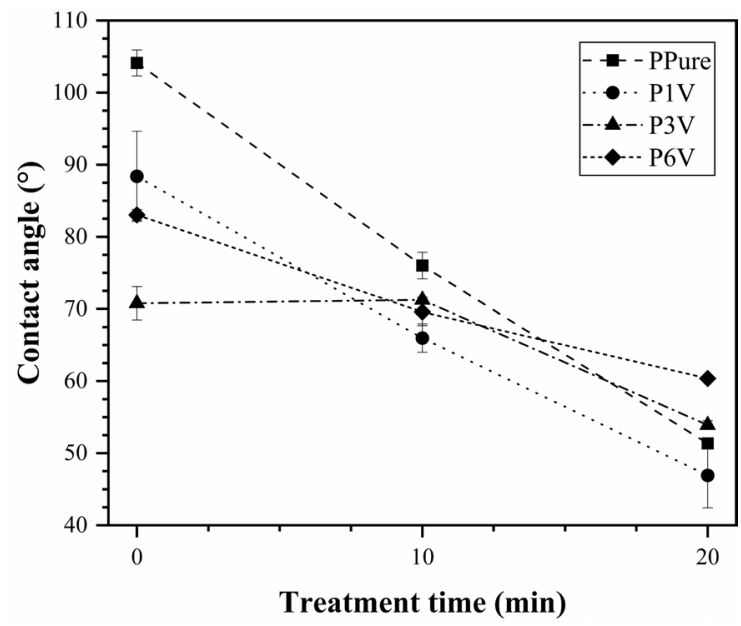

Figure 1. The contact angle of flat films treated according to $\mathrm{C}_{1}$.

The hydrophilicity of clay hinders the mixing and interaction of natural silicates with non-polar polymers ${ }^{15}$. In addition, the VMT clay presents negative charges, such as substitutions in the tetrahedral and octahedral networks, so it is expected that the water will be attracted to the surface by the hydration capacity, involving the ion-dipole attraction of the involved ions ${ }^{16}$.

On the other hand, with the application of $\mathrm{C}_{1}$ on the PPure film surface, there was a change in the surface characteristic, from hydrophobic to hydrophilic, since there was a marked reduction of the angle from $104.12^{\circ}$ to $76.01^{\circ}$ in $10 \mathrm{~min}$ of treatment. When treated for $20 \mathrm{~min}$, the contact angle of the PPure film decreased to $51.35^{\circ}$, therefore, there was a greater reduction when increasing the time of plasma exposure. This fact is related to the surface free energy of the films, which increased with the longer time of plasma exposure, as a result, the contact angle decreased. This condition is associated with the high free energy of solid surfaces since water has a high surface tension and spreads with low contact angle on these surfaces ${ }^{11}$. MACÊDO et al. (2012) $)^{17}$ indicated that the wettability is altered by the presence of polar and non-polar surface groups, thus, the decrease in angle is indicative of the addition of hydrophilic groups on the surface. WANG et al. $(2012)^{18}$ also stated that the increase of the surface polar molecules in the material causes the reduction of the contact angle.

For the P1V film, a reduction of the contact angle with the plasma treatment was observed from $88.39^{\circ}$ to $65.96^{\circ}$ after $10 \mathrm{~min}$ of treatment, and when applied for $20 \mathrm{~min}$, the angle was reduced to $46,91^{\circ}$. For the P6V film, there were moderate reductions, in which, with the application of $10 \mathrm{~min}$ of treatment the angle reduced from $83.04^{\circ}$ to $69.59^{\circ}$, and with $20 \mathrm{~min}$, to $60.37^{\circ}$. The P3V film when treated during $10 \mathrm{~min}$ did not present a significant reduction of contact angle, however, after the treatment for $20 \mathrm{~min}$, it was noticed that there was an expressive reduction from $70.79^{\circ}$ to $53.9^{\circ}$.
In sum, the contact angle was reduced with the application of plasma under $\mathrm{O}_{2}$ atmosphere $\left(\mathrm{C}_{1}\right)$, probably due to the incorporation of oxygenated species after treatment, increasing the surface wettability of the films ${ }^{19}$. LE and HSU (2010) $)^{20}$ stated that the duration of plasma treatment directly affects the contact angle and surface wetting of the material, in what way the longer treatment leads to a lower contact angle. The contact angles are not stable and will vary over time to stabilize, though. According to the authors, PPure films and biocomposites treated for $20 \mathrm{~min}$ showed the lowest contact angle values. The literature reports that $\mathrm{O}_{2}$ is probably the gas most widely used for surface modification of plasmatreated polymers due to the addition of polar groups on the polymer surface, thus improving wettability ${ }^{21}$.

The Figure 2 shows the wettability behavior of PPure, P1V, P3V and P6V films that were exposed to $\mathrm{C}_{2}$, where time 0 (zero) refers to films that did not receive plasma treatment, and the time of 10 and 20 min refers to the films treated in that condition.

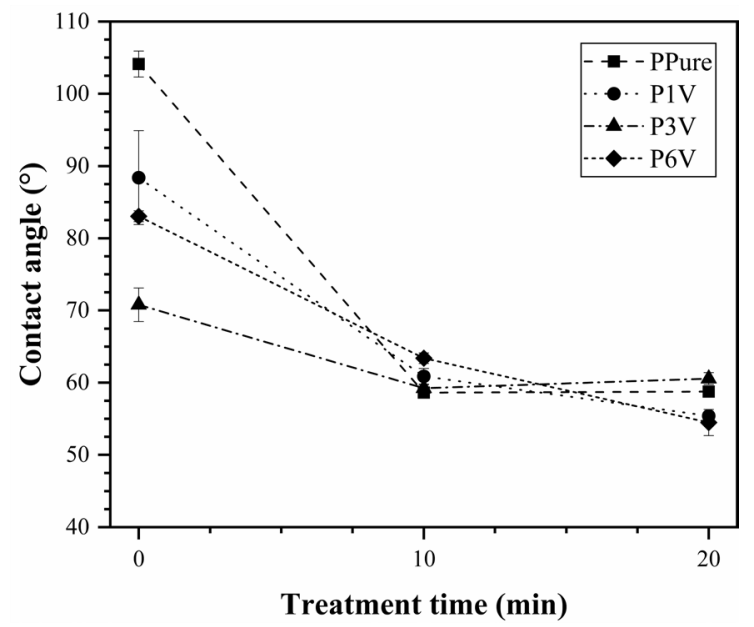

Figure 2. The contact angle of flat films treated according to $\mathrm{C}_{2}$.

It was verified through Figure 2 that a progressive reduction of the contact angle values happened as a function of the increased time of plasma exposure, this reduction is related to the pre-treatment applied. Accordingly, with only $10 \mathrm{~min}$ of treatment was verified a great efficiency in the results, however, it can be noticed that with $20 \mathrm{~min}$ there was little change when compared to the treatment with 10 min. This statement is more evident when the values of contact angle for the PPure were presented, which without treatment showed the contact angle of $104.12^{\circ}$ and after treatment for $10 \mathrm{~min}$, it reduced to $58.61^{\circ}$, when applied for $20 \mathrm{~min}$, the angle reduced to $58.75^{\circ}$. A possible explanation for these equivalent values may be related to the longer time of exposure to plasma, which may have saturated the films surfaces with $10 \mathrm{~min}$ of treatment after the pre-treatment, consequently when applied the 20 min treatment, possibly, the surface was already activated. 
In relation to the biocomposites, when the treatment was applied for $10 \mathrm{~min}$, the contact angle of the P1V film was reduced from $88.39^{\circ}$ to $60.88^{\circ}$, in the application for $20 \mathrm{~min}$, the angle was reduced to $55.4^{\circ}$. Similarly, the P6V film was reduced from $83.04^{\circ}$ to $63.39^{\circ}$ after $10 \mathrm{~min}$ and to $54.47^{\circ}$ after $20 \mathrm{~min}$. Only the P3V film presented different behavior, in the application for $10 \mathrm{~min}$ the contact angle reduced from $70.79^{\circ}$ to $59.23^{\circ}$, and after application of the treatment for $20 \mathrm{~min}$ the angle, was practically unaffected, presenting values similar to the PPure film. These results with significant reductions when using the VMT clay may be related to the modification in the clay interlayers, according to results obtained by VALDRÈ et al. $(2007)^{22}$, after the VMT treatment with $\mathrm{Ar}$ and $\mathrm{H}_{2}$ plasma at room temperature, the authors concluded that the plasma gases induced several modifications in the clay layer, since the chemical analysis showed a significant reduction in the interlayer cation content, especially for samples treated under $\mathrm{H}_{2}$ atmosphere.

The main consequence of plasma treatment under Ar atmosphere is the transfer of energy from plasma species to the polymer surface since it is an inert gas and consequently there is no possibility of chemical reactions between it and the organic surface ${ }^{23}$. On the other hand, PELAGADE et al. $(2012)^{24}$ reported that the film exposure to Ar discharge is sufficient to break the chemical bonds $\mathrm{C}-\mathrm{C}$ and $\mathrm{C}-\mathrm{H}$, leaving free radicals on or near the surface. In relation to the use of $\mathrm{H}_{2}$, it has probably also been active in the formation of reactive species, as reported by MACÊDO et al. $(2010)^{25}$ that applied the plasma under
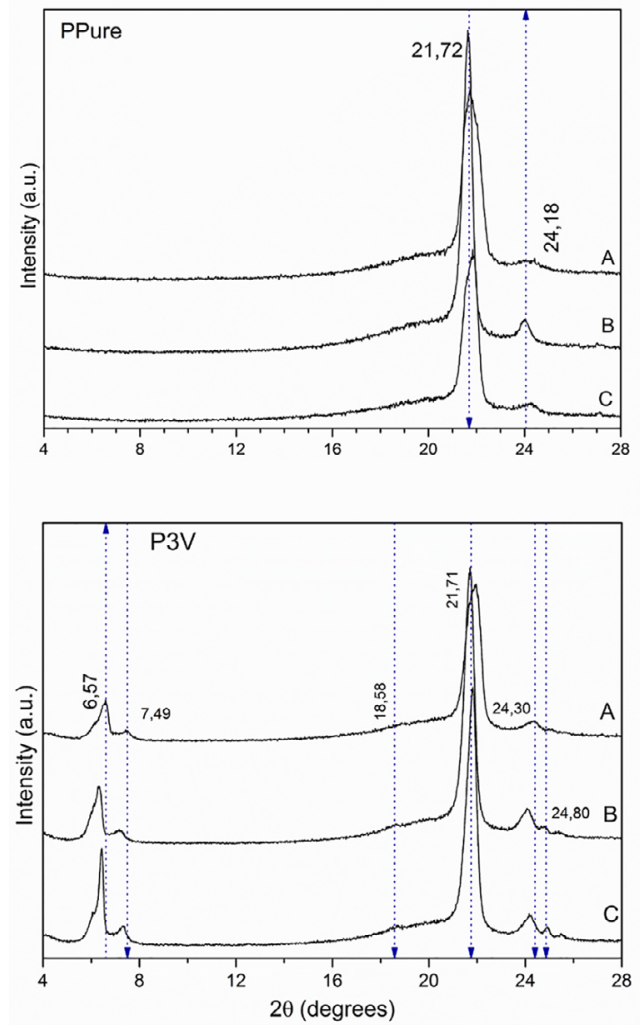

Figure 3. Diffractograms of PPure, P1V, P3V, and P6V films: no treatment (A); treated through $\mathrm{C}_{1}$ in the time of $10 \mathrm{~min}$ (B) and $20 \min (\mathrm{C})$.
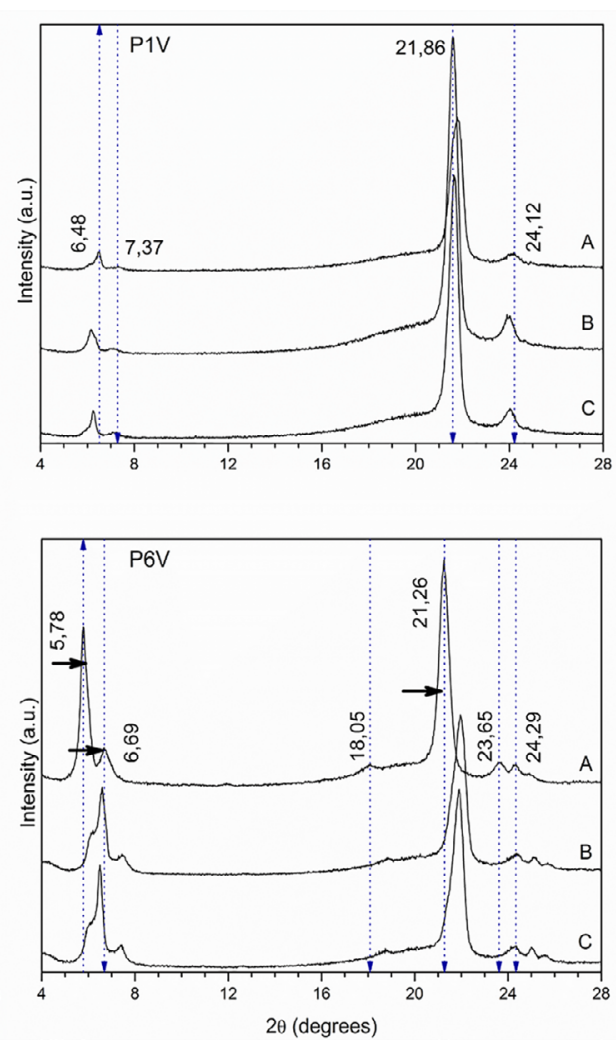

$\mathrm{H}_{2}$ atmosphere in chitosan membranes for biomedical purposes, it was confirmed the formation of active sites on the surface changing the roughness, texture, and wettability.

The pre-treatment application causes a high reactivity on the samples surface and, consequently, a noticeable reduction of the contact angle occurs. This process occurs because the gas mixture causes the acceleration of the plasma ions towards the polymer surface, providing a higher reactivity of the exposed surface, according to PASCU et al. $(2003)^{23}$, this is possible due to the disruption of different bonds and subsequent formation of free radicals.

The films of PPure, P1V, and P3V presented the highest reductions of contact angle when treated in the $\mathrm{C}_{1}$ condition for $20 \mathrm{~min}$, whereas the $\mathrm{P} 6 \mathrm{~V}$ film exhibited a greater reduction when exposed to $\mathrm{C}_{2}$ for $20 \mathrm{~min}$. These results evidenced the efficiency of the longer exposure time to the plasma under $\mathrm{O} 2$ atmosphere for the films, in which the best results were obtained. Therefore, the surface functionalization of the films by the formation of free radicals is really important, since the Green PE does not hold groups containing the oxygen in its chemical composition ${ }^{26}$ (PRAT et al., 1997).

\subsection{X-Ray Diffraction}

The Figure 3 shows the diffractograms of PPure films and of films with the addition of 1,3 and $6 \%$ of VMT. The results obtained are related to the films that did not receive plasma treatment and the films that were treated according to $\mathrm{C}_{1}$. 
Onwards the Figure 3 it is possible to observe some of the characteristic spike of the PE around $21.72^{\circ}$ and $24.18^{\circ}$. These diffraction spikes are related to the orthorhombic structure of the PE, which represent the reflection planes (110) and (200), respectively ${ }^{27,28}$. It was noted that the plasma treatment under $\mathrm{O}_{2}$ atmosphere did not modify significantly the crystalline structure of the films, hence, considering the wettability results that evidenced the surface hydrophilicity of the films, it is assumed that the plasma treatment reached only the initial atomic layers on the surface.

With insertion of VMT, new spikes occurred in $2 \theta$, equal to $6,48^{\circ}$ and $7,37^{\circ}, 18,05^{\circ}$ and $24,29^{\circ 29,30}$. It was observed that with the higher incorporation of VMT content there was an increase in the intensity of these spikes, which indicated the presence of charge in the material structure. In the application of $\mathrm{C}_{1}$, were observed small movements of the spikes attributed to the load. It was also verified that the greatest movements occurred for the films with the highest content of VMT, more significant for the P6V film, which may indicate that small changes occurred in the crystallographic plane structure of this film.

The diffractograms of Figure 4 depict the results obtained for the PPure films and for the P1V, P3V, and P6V systems without the treatment and after treatment by means of $\mathrm{C}_{2}$.

The diffractograms of PPure film indicated that despite the increase of a pre-treatment, there were no significant changes in the structure of the films, a similar result using $\mathrm{C}_{1}$. For the P1V, P3V, and P6V films the characteristic VMT clay spikes were observed around $6.48^{\circ}, 7.37^{\circ}$ and those that appeared or intensified due to the higher VMT content at $18.11^{\circ}, 24.83^{\circ}$, and $25^{\circ}$. Thus, with the application of $\mathrm{C}_{2}$, small movements of these spikes occurred, in comparison to $\mathrm{C}_{1}$, in a subtler way. However, similar to $\mathrm{C}_{1}$ the movements were more evident with the higher VMT content.
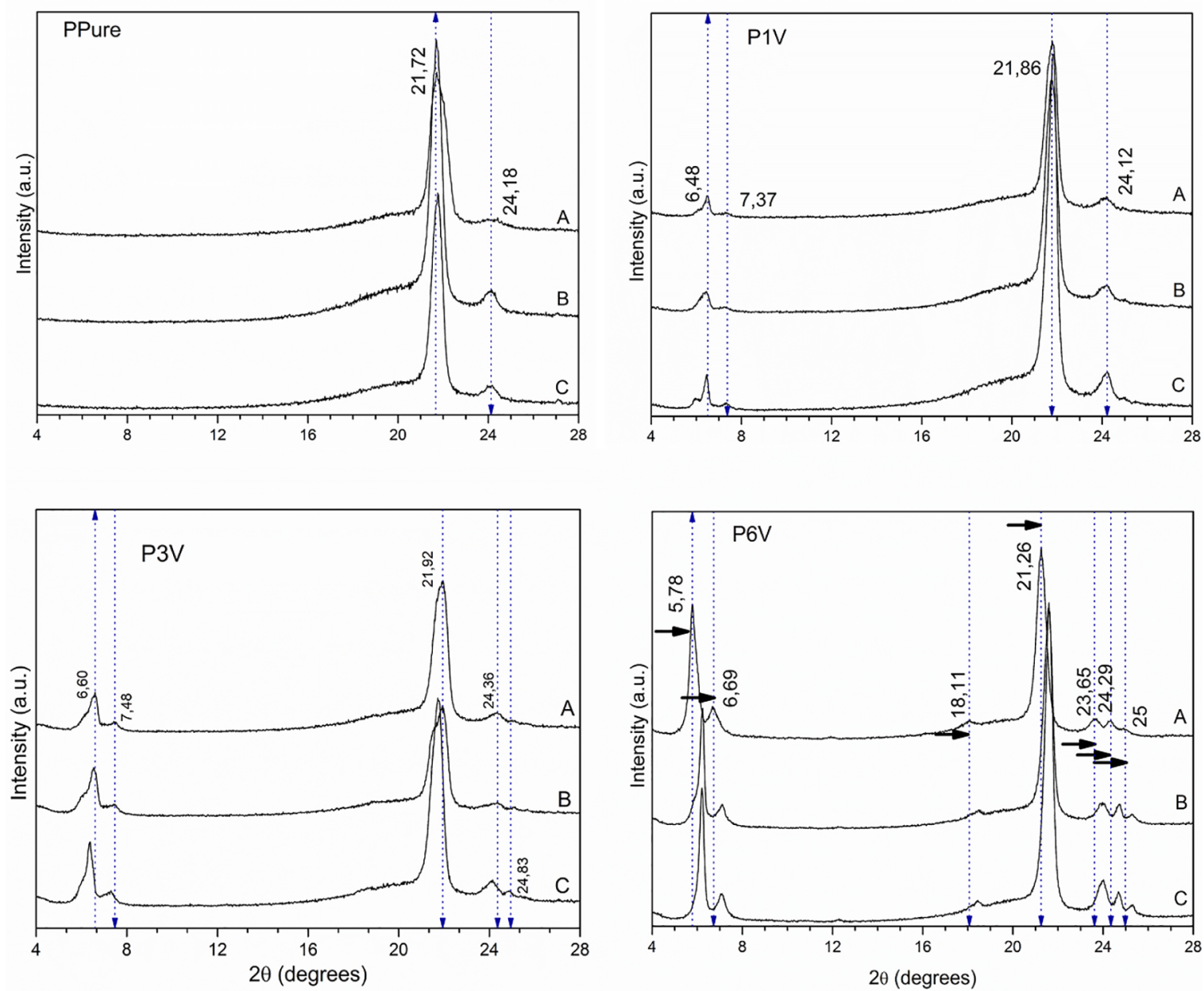

Figure 4. Diffractograms of PPure, $P 1 V, P 3 V$, and P6V films: no treatment (A); treated through $C_{2}$ in the time of 10 min (B) and 20 min (C). 


\section{Conclusions}

The results obtained in this work allowed to conclude that the incorporation of VMT and the conditions used for the plasma treatment increased the wettability of the films without changing their structure. Therefore, it was verified that the untreated PPure presented a hydrophobic surface, and the addition of the VMT clay caused an increase in hydrophilicity. The $\mathrm{C}_{2}$ exhibited more efficiency in the surface treatment of films. The diffractograms indicated that there were no significant changes in the structure of the films with the plasma treatment application in the two studied conditions. Hence, the P1V, P3V, and P6V films acquired a hydrophilic character without compromising their structure.

\section{Acknowledgements}

The authors thank the Graduate Program in Materials Science and Engineering (CT-UFPI), Laboratory of Polymer and Conjugated Materials - LAPCON/UFPI, Plasma Laboratory - LabPlasma/UFPI, Capes and CNPq for financial support (Process: 446655/2014-7, 306312/2015-8 and 446530/2014-0).

\section{References}

1. Faria AC. Considerações gerais sobre aditivação em poliolefinas. Boletim da Sociedade Portuguesa de Química. 1986;24(2):12-15.

2. Chung TCM. Functional Polyolefins for Energy Applications. Macromolecules. 2013;46(17):6671-6698.

3. Candian LM. Estudo do polietileno de alta densidade reciclado para uso em elementos estruturais. [Dissertation]. São Carlos: University of São Paulo; 2007.

4. Kwon OJ, Myung SW, Lee CS, Choi HS. Comparison of the surface characteristics of polypropylene films treated by $\mathrm{Ar}$ and mixed gas $\left(\mathrm{Ar} / \mathrm{O}_{2}\right)$ atmospheric pressure plasma. Journal of Colloid and Interface Science. 2006;295(2):409-416.

5. Salmoria GV, Martins WFM, Fúcio DM. Tratamento da superfície de cateteres de poliamida 11 por plasma de oxigênio. Polímeros. 2013;23(4):565-569.

6. Van Deynse A, Cools P, Leys C, Morent R, De Geyter N. Surface modification of polyethylene in an argon atmospheric pressure plasma jet. Surface and Coatings Technology. 2015;276:384-390.

7. Assis OBG. Alteração do caráter hidrofílico de filmes de quitosana por tratamento de plasma de HMDS. Química Nova. 2010;33(3):603-606.

8. Ghiggi FF. Preparo e caracterização de membranas de ultrafiltração de polietersulfona/ftaloilquitosana com propriedade antifouling. [Dissertation]. Porto Alegre: Federal University of Rio Grande do Sul; 2014.

9. Vandencasteele N, Reniers F. Plasma-modified polymer surfaces: Characterization using XPS. Journal of Electron Spectroscopy and Related Phenomena. 2010;178-179:394-408.

10. Luz AP, Ribeiro S, Domiciano VG, Brito MAM, Pandolfelli VC. Avaliação do molhamento da matriz de um concreto refratário $\left(\mathrm{Al}_{2} \mathrm{O}_{3}-\mathrm{SiC}-\mathrm{SiO}_{2}-\mathrm{C}\right)$ por escórias sintéticas contendo distintos teores de MgO. Cerâmica. 2012;58(346):144-150.
11. De Geyter N, Morent R, Leys C. Surface characterization of plasma-modified polyethylene by contact angle experiments and ATR-FTIR spectroscopy. Surface and Interface Analysis. 2008;40(3-4):608-611.

12. Tunney JJ, Detellier C. Aluminosilicate Nanocomposite Materials. Poly(ethylene glycol)-Kaolinite Intercalates. Chemistry of Materials. 1996;8(4):927-935.

13. Garcés JM, Moll DJ, Bicerano J, Fibiger R, McLeod DG. Polymeric Nanocomposites for Automotive Applications. Advanced Materials. 2000;12(23):1835-1839.

14. Wolf FG, dos Santos LOE, Philippi PC. Formação e dinâmica da interface líquido-vapor simulada pelo método Lattice-Boltzmann. Revista Brasileira de Ensino de Física. 2006;28(2):167-175.

15. Gomes EVD, Visconte LLY, Pacheco EBAV. Processo de organofilização de vermiculita brasileira com cloreto de cetiltrimetilamônio. Cerâmica. 2010;56(337):44-48.

16. Schrader ME, Yariv S. Wettability of clay minerals. Journal of Colloid and Interface Science. 1990;136(1):85-94.

17. Macêdo MOC, Macêdo HRA, Silva GC, Silva MAM, Júnior CA. Estudo comparativo da modificação superficial de membranas de quitosana tratadas por plasma de oxigênio, nitrogênio e hidrogênio. Revista Eletrônica de Materiais e Processos. 2012;7(2):95-103

18. Wang K, Li J, Wang SQ. The surface modification of a polyethylene (PE) film using an air Coplanar barrier discharge plasma at atmosphere pressure. In: Proceedings of $2^{\text {nd }}$ International Conference on Electronic \& Mechanical Engineering and Information Technology (EMEIT 2012); 2012 Sep 7; Shenyang, China. p. 1038-1042.

19. Mao H, Hu F, Ye QL, Xu Y, Yang X, Lu B. Manipulating the charge transfer at $\mathrm{CuPc} /$ graphene interface by $\mathrm{O}_{2}$ plasma treatments. Nanoscale. 2014;6(14):8149-8154.

20. Le NB, Hsu YC. Investigation of hydrophilic modification for bubble-free operation in microfluidic systems and micropump applications. Advances in Natural Sciences: Nanoscience and Nanotechnology. 2010;1(1):015006.

21. Øiseth SK, Krozer A, Kasemo B, Lausmaa J. Surface modification of spin-coated high-density polyethylene films by argon and oxygen glow discharge plasma treatments. Applied Surface Science. 2002;202(1-2):92-103.

22. Valdrè G, Malferrari D, Marchetti D, Brigatti MF. The effect of different plasma gas environments on vermiculite layer. Applied Clay Science. 2007;35(1-2):76-84.

23. Pascu M, Vasile C, Gheorghiu M. Modification of polymer blend properties by argon plasma/electron beam treatment: surface properties. Materials Chemistry and Physics. 2003;80(2):548-554.

24. Pelagade SM, Singh NL, Qureshi A, Rane RS, Mukherjee S, Deshpande UP, et al. Investigation of surface properties of Ar-plasma treated polyethylene terephthalate (PET) films. Nuclear Instruments and Methods in Physics Research B: Beam Interactions with Materials and Atoms. 2012;289:34-38.

25. Macêdo MOC, de Macêdo HRA, dos Santos ZM, Pereira MR, Alves Júnior C. Avaliação da modificação de membranas de quitosana tratadas por plasma de hidrogênio para aplicações biomédicas. Revista Brasileira de Aplicações de Vácuo. 2010;29(1-2):31-36 
26. Prat R, Shi MK, Clouet F. Interactions of Cold Plasmas with Polymers and Their Model Molecules: Degradation vs. Functionalzation. Journal of Macromolecular Science, Part A: Pure and Applied Chemistry. 1997;34(3):471-488.

27. Wei P, Bai S. Fabrication of a high-density polyethylene/ graphene composite with high exfoliation and high mechanical performance via solid-state shear milling. RSC Advances. 2015;5(114):93697-93705.

28. Mahmoud ME, El-Khatib AM, Badawi MS, Rashad AR, ElSharkawy RM, Thabet AA. Recycled high-density polyethylene plastics added with lead oxide nanoparticles as sustainable radiation shielding materials. Journal of Cleaner Production. 2018;176:276-287.

29. Ugarte JFO, Monte MBM, França SCA, Graciano FPR. Comparação Estatística do Fator de Expansão de Concentrados de Vermiculita. In: XX Encontro Nacional de Tratamento de Minérios e Metalurgia Extrativa; 2004 Jun 15-18; Florianópolis, SC, Brazil. p. 201-208.

30. Fernandes MVS, da Silva LRD. Síntese e caracterização de vermiculita mesoporosa obtida por modificação com sais complexos de alumínio e lantânio. Cerâmica. 2014;60(354):205-210. 